\title{
Sustainable Development and its Impact on the Quality of Human Capital
}

\author{
Sylvia Bukovová ${ }^{1}$ Lubica Foltínová $^{1 *}$ \\ ${ }^{1}$ University of Ecnomics in Bratislave, Dolnozemská 1, 85235 Bratislava
}

\begin{abstract}
The quality of human capital depends on the conditions in which people live, work and learn. Therefore, the issue of sustainable development as a prerequisite for ensuring the existence and development of human capital is at the center of attention of the governments of each country. The article describes sustainable development, presents its goals and strategies to be achieved at European and national level. The aim of the research is to assess the current state and development of selected indicators of sustainable development related to the quality of human capital in Slovakia and other V4 countries in the period from 2014 to 2018.
\end{abstract}

\section{Introduction}

Use Labor as a factor of production is becoming increasingly important in the era of globalisation. The efficiency of business processes, as well as the quality of their outputs depends on this factor, therefore it plays a crucial role in securing the competitiveness of the corporation, economy as well as economic space. The quality of this productive factor represented by people with their abilities, knowledge and skills to produce goods and offer services, is dependent on the conditions in which people live, work and learn. Therefore, the issue of sustainable development as a prerequisite for ensuring the existence and development of human capital is at the center of attention of the governments of each country[17].

\subsection{Sustainable development}

Sustainable development, which means meeting the needs of present generations without jeopardizing the needs of future generations, has been the leading motive behind mankind political, economic and environmental activities for many years. It is a comprehensive approach that integrates the economic, social and environmental aspects in a synergistic way, linking thus the present with the future[10]:

The concept of sustainable development includes according to the IHK the following aspects [3]:

\footnotetext{
* Corresponding author: lubica.foltinova@euba.sk.
} 
- it strives to balance economic, social and environmental goals

- it represents mutually interconnected processes of searching, understanding, learning and empathy

- it is a decisive strategic competitive factor for the economy

- it represents a creative process which requires a new understanding of politics

The definition of the term sustainable development has a strong interdisciplinary character. So far, however, there is no uniformly accepted definition of it. It is generally understood as a form of ecological and economic activity designed to provide comparable or better living conditions for present and future generations. The focus is on the environment, the economic and social aspects of society.

The European Parliament has defined sustainable development as the improvement of the standard of living and well-being of people within the limits of ecosystem capacity while preserving natural values and biodiversity for present and future generations.

Several definitions focus on the following aspects:

- sustainability is always focused on the present and the future containing thus a temporal dimension

- resources - material and intangible goods, economic / ecological units and p. should be protected, especially when they are not renewable

- the continuity of the particular object should be sustained not only in short term but also in the long term.

As a rule, the concept of sustainable development is attributed to three different problem dimensions that need to be taken into account while respecting the political objectives of sustainable development. According to BPB (2008), these are the economic, ecological and social dimensions of sustainability, which, however, take on different value in practical implementation $[1,5]$ :

- The economic dimension of sustainability focuses on preserving capital on long-term returns, based on efficient and long-term use of existing resources, thus differentiating from the logic of short-term gains of continuous economic growth, while continuing to support the gradual quantitative growth that is needed. to combat chronic shortages in the poorest countries in terms of catching up in rich developed countries.

- On the other hand, the environmental dimension of sustainability highlights the empirically hardly measurable intrinsic value of nature itself and the definitive nature of natural resources, which implies the economic necessity of preserving existing natural capital and preserving the ecological conditions of human survival. In terms of a qualitative understanding of economic development, ecological costs of production and consumption must therefore be taken into account in the global economy.

- The focus of social dimension is the issue of distributive justice in distribution. This concerns the access to opportunities and resources not only within individual countries and societies, but also in the conflict of the global division of the world between rich industrialized countries and poor, highly indebted developing countries. In addition to meeting the basic needs of present and future generations, the social dimension explicitly addresses gender issues in terms of creating a fairer environment for women and men.

The following figure shows the dimensions and sustainability strategies in their mutual interconnection: 


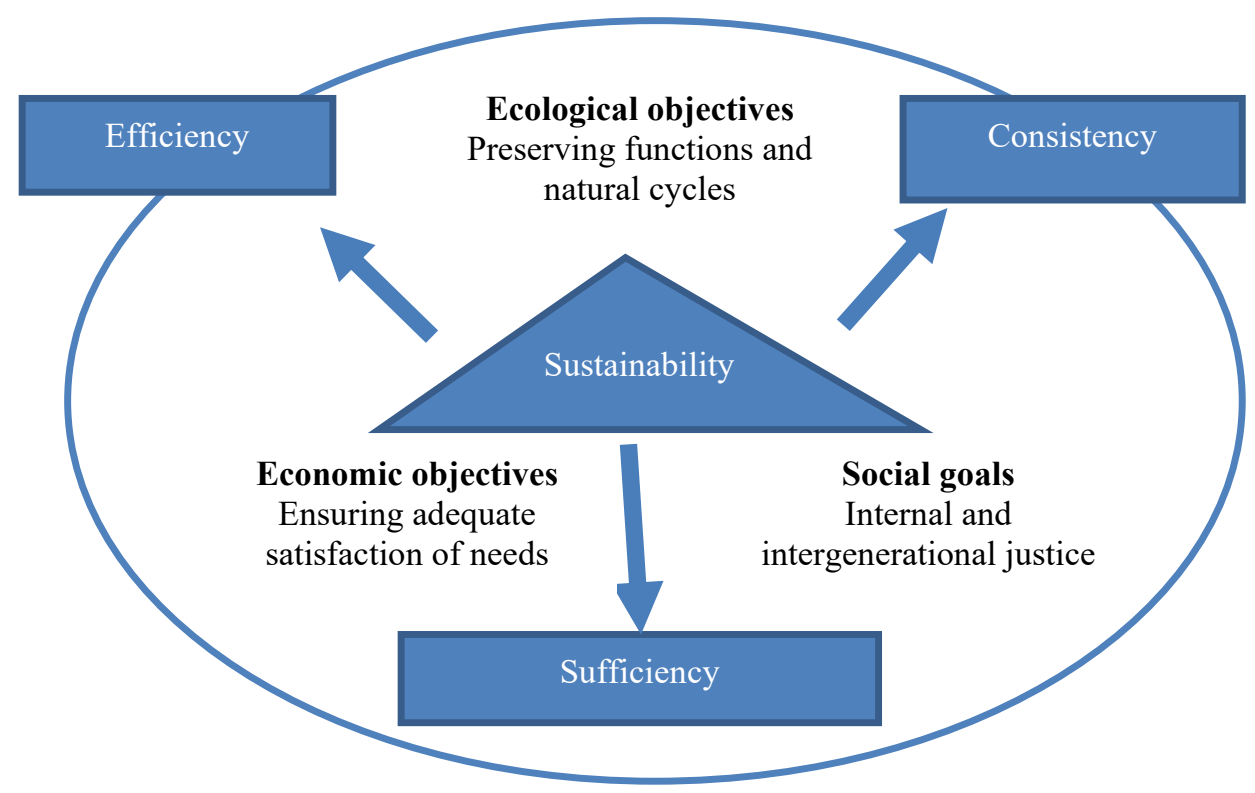

Fig. 1. Sustainability dimensions and strategies Below the figure [1].

Act no. 17/1992 Coll. on the Environment (§ 6) defines sustainable development as a development that preserves the possibility for current and future generations to meet their basic living needs, while not reducing the diversity of nature and preserving the natural functions of ecosystems

The Slovak National Sustainable Development Strategy \& Agenda 2030 [7,8] describe it as a targeted, long-term, comprehensive and synergistic process, affecting conditions and all aspects of life, at all levels and towards a functional model of a community that satisfies biological, material, spiritual and social needs and interests of people, while eliminating or significantly reducing interventions threatening, damaging or destroying conditions and life forms, does not burden the country beyond the bearable extent, rationally uses its resources and protects cultural and natural heritage [11,19].

\subsection{Agenda 2030 and Sustainable Development Goals}

At the historic United Nations Summit in New York in September 2015 leaders around the world committed themselves to ending poverty, fighting climate change and injustice. The United Nations Program, entitled We are transforming our world: The Sustainable Development Program by 2030 - Agenda 2030 was adopted, setting a set of objectives for sustainable development in order to halt poverty, protect the planet, ensure the protection of human rights and guarantee prosperity for all.

The adoption of this program is a historic milestone on the road to a new model of the world because it addresses economic, social and environmental disparities in a global and integrated way. The European values of social justice, democratic governance and the social market economy, as well as environmental protection, are fully reflected in this process.

The 2030 Agenda for Sustainable Development offers a better future not only for billions of people around the world, but also for the planet itself. 193 countries have unanimously adopted the following sustainable development goals [9]: 
1. No poverty - to end and eradicate poverty everywhere and in all its forms, anywhere in the world

2. No hunger - to eliminate hunger and malnutrition, ensure food security and better nutrition, and promote sustainable agriculture

3. Quality of health and life - to ensure a healthy life and promote well-being for all and at every age

4. Quality education - to ensure inclusive, high quality and fair education of equal quality for all, to support lifelong learning

5. Gender equality - to achieve gender equality and to empower the position and women and girls in society

6. Clean water and sanitation - to ensure water availability, sustainable water management and sanitation for all

7. Clean energy - to ensure access to affordable, sustainable and modern energy for all

8. Decent work and economic growth - to support sustainable, inclusive and sustainable economic growth, full and productive employment and decent work for all

9. Infrastructure - to build resilient infrastructure, to support inclusive and sustainable industrialization, to foster innovation

10, Reduction of inequalities - to reduce inequalities within and between countries

11. Sustainable cities and communities - to create safe and resilient cities and human settlements

12. Responsible consumption and production - to ensure sustainable consumption and production patterns

13. Climate protection - to take immediate steps to combat climate change and its consequences

14. Life under water - to preserve and sustainably use the oceans and seas and sea resources for sustainable development

15. Life on the mainland - to protect land ecosystems, to support sustainable forest management, to fight desertification and to stop land degradation and biodiversity loss

16. Peace, justice and powerful institutions - to promote a peaceful, inclusive society for sustainable development, to ensure access to justice for all, to create effective, transparent and accountable institutions at all levels

17. Partnership for objectives - to strengthen the means of implementation and revitalize the Global Partnership for Sustainable Development

These sustainable development objectives ensure a balance between the three dimensions of sustainable development: economic, social and environmental. They represent specific goals for the next 15 years and focus on areas such as [2]:

- human dignity,

- regional and global stability,

- a healthy planet,

- fair and resilient societies,

- prosperous economy.

This universal and indivisible Agenda challenges all - developed and developing countries as well as people - to achieve the goals of ending poverty, fighting inequality and combating climate changes by $2030 \mathrm{EC}$ [12].

\subsection{The EU and sustainable development}

A number of strategies, programs and plans have been developed at European level since the United Nations Conference on Sustainable Development in Rio de Janeiro in 
1992. As early as 2001, the EU adopted a long-term Strategy for Sustainable Development, which contains a number of specific objectives and proposals for improving European policy. These objectives are pursued in individual European countries through national sustainability strategies.

\subsubsection{Related strategies}

According to LS (2020), the strategies are as follows [4]:

2005 - Strategy for the sustainable use of natural resources

2006 - A renewed strategy for sustainable development

2009 - Report on the implementation of the Community Lisbon Program in. 2008 -2010

2010 - European Sustainability Strategy 2010 - Europe 2020 Strategy Represents a growth strategy to deliver smart, sustainable and inclusive growth across the EU.

2011 - The Roadmap to a resource-efficient Europe - Strategy Europe 2020 flagship initiative

2011 - White Paper on competitive and resource efficient transport by 2050

2011 - EU Strategy (2011-2014) on Corporate Social Responsibility

2013 - 7. EU Environmental Action Program 2020

2014 - Horizon 2020 - EU Research Framework Program - 2014-2020

2014 - European Union Alpine Space Strategy - Action Plan

2016 - Towards a sustainable future - European sustainability policy

2017 - EU response to Agenda 2030: Council conclusions of 20.06.2017

Furthermore, mitigation and adaptation measures have been developed - Klimaroadmap 2050 and Energieroadmap 2050.

In November 2016, the European Commission presented its strategic approach to the implementation of the 2030 Sustainable Development Program, including the Sustainable Development Goals. The EU has a strong starting position in the field of sustainable development and, together with its member countries, is committed to leading the implementation of the UN agenda by 2030. The Agenda promotes convergence between EU countries, within societies and with the rest of the world, setting a new universal standard for sustainable development for the benefit of all the people of the planet. Sustainable development goals are part of all10 priorities of the European Commission .

The key measures for implementing the 2030 program are [2]:

- to mainstream sustainable development objectives into all policies and initiatives, with sustainable development becoming the guiding principle that will guide all Commission policies,

- regular reporting on EU progress (first report in 2017),

- ensuring the successful implementation of the 2030 program together with EU Member State governments, the European Parliament, other European institutions, international organizations, civil society organizations, citizens and other stakeholders,

- launching a high-level multi-stakeholder platform, to promote the exchange of best practice in the implementation of the program in different sectors at national and EU level;

- developing a longer-term vision for the post-2020 period.

In order to promote sustainable development in the world, the EU will continue to work with external partners, making use of all the instruments at its disposal in the framework of external policy and, in particular, supporting efforts in developing countries.

\subsubsection{The EC has set 10 priorities for sustainable development}

\section{Jobs, Growth and Investment}


The aim is to stimulate investment and create job opportunities. Since the global economic and financial crisis, the EU has suffered from low investment rates. Coordinated efforts at European level are needed to put Europe on the road to economic recovery. Investment plan for Europe, so called Juncker plan aims to create jobs and promote growth by making more intelligent use of financial resources, removing barriers to investment, raising the profile of investment projects and providing technical assistance.

\section{Digital Single Market}

The Internet and digital technologies are transforming the world. Existing online barriers, however, prevent citizens from accessing goods and services, internet companies and startups are limited in scope, and businesses and governments cannot make full use of digital tools. It is therefore essential to prepare the EU single market for the digital age - by removing regulatory barriers and moving from national markets to a single market. It could bring the economy $€ 415$ billion a year and hundreds of thousands of new jobs

\section{Energy Union and Climate}

The European Energy Union will ensure that Europe has secure and affordable climatefriendly energy. Smarter use of energy, while fighting climate change, is a stimulus to create new jobs and to invest in Europe's future. The state of the Energy Union has shown progress since the adoption of the Energy Union Framework Strategy for the transition to a low-carbon, secure and competitive economy.

\section{Internal Market}

The single market is one of Europe's greatest achievements as well as its greatest asset in times of increasing globalization. It is the engine for building a stronger and fairer EU economy. The freedom of movement of people, goods, services and capital brought by the single market offers new opportunities for citizens, workers, entrepreneurs and consumers, thus contributing to job creation and long-term growth. Integrated capital markets will provide more funding to companies, in particular SMEs, and to infrastructure projects. Improved labor mobility will allow people to move more freely where their skills are needed. Combating tax evasion and tax fraud will ensure that everyone contributes a fair share.

\section{Deeper and Fairer Economic and Monetary Union}

- Within the Economic and Monetary Union (EMU), the economic policies of EU countries are coordinated with an aim to:

- support investment and increase competitiveness

- create more jobs and better living conditions.

Currently, the reinforcement of the EMU structure is being addressed, which will enable it to respond to challenges more quickly and decisively in the future.

\section{A Balanced and Progressive Trade Policy to Exploit Globalization}

In the current world economy, trade is a prerequisite for growth, employment and competitiveness. The EU is committed to maintaining an open trading system. EU trade policy helps to create new jobs and new business and investment opportunities for large and small corporations. For consumers, trade agreements bring lower prices and more choice, while maintaining stringent EU consumer protection standards, social rights and environmental rules. At the same time, trade policy promotes Europe's influence in the world, spreads European values and attracts new investment. And the trade agreements help to achieve all these goals. 


\section{Justice and Fundamental Rights}

The purpose is to promote cooperation between the different EU judicial systems and to protect the rule of law Every EU citizen has the same fundamental rights as a result of the values of equality, non-discrimination, inclusion, human dignity, freedom and democracy. These values are strengthened and protected by the rule of law enshrined in the EU Treaties and the Charter of Fundamental Rights.. The Commission has been working to enable EU citizens to cross borders without difficulty, whether to live, work, study or marry in another EU country, while protecting their personal data and improving their position as consumers.

Peace is one of the fundamental principles of the EU and requires effective and appropriate access to terrorism, trafficking in human beings and cybercrime.

\section{Migration}

The fate of the thousands of migrants who have risked their lives to reach the EU is shocking. Obviously, no EU country can face enormous migration flows on its own and should not be left alone to tackle them. To tackle this problem The European Commission's Migration Program provides for the integration of internal and external policies, the use of EU agencies and instruments, and the involvement of all actors: EU countries and institutions, international organizations, civil society, local authorities and national partners outside the EU.

\section{A Stronger Global Actor - Pooling External Politics Instruments}

The EU needs a strong common foreign policy to:

- respond effectively to global challenges, including crises in its neighborhood,

- spread its values,

- reject protectionism and maintain EU business standards; and

- contribute to peace and prosperity in the world.

\section{Democratic Change}

In 2014, for the first time, EU countries had to take into account the results of the elections when proposing a candidate for the position of the President of the European Commission. Although this was an important step, it is only the first of many on the road to a more democratic European Union and its getting closer to citizens. Europeans have the right to know who the Commissioners, Commission staff, MEPs and Council representatives are meeting in the legislative process. The Commission is committed to giving fresh impetus to its relationship with the European Parliament, while working more closely with national parliaments.

\subsection{National Strategy Agenda 2030}

The Slovak Republic signed up for the implementation of the 2030 Agenda in the document "Background to the implementation of the 2030 Agenda for Sustainable Development" approved by Government Resolution no. 95/2016. Sustainable development can, however, only be ensured by integrating it into all public policies.

The process of implementing the objectives of the 2030 Agenda on a national level is based on the fact that the topic of sustainable development is not new in the country. It makes it possible to build on existing activities and focus on reviving efforts to implement previously elaborated, more or less completed sectoral strategies and activities, in particular the National Sustainable Development Strategy adopted by the Slovak Government in 2001.

Achievement of Sustainable Development Goals in Slovakia 
Agenda 2030 represents an opportunity and an instrument o identify long-term priorities for the development of Slovakia. It will be reflected in a narrower set of six priority areas which take into account the specific features of Slovakia and which will form the basis for further strategic and conceptual work. Six priorities for sustainable development have been set for Slovakia's development by 2030:

Directing towards a knowledge-based, environmentally sustainable and circular economy in the face of demographic change and a changing global environment:

- Education for a dignified life,

- Good health

- Sustainable settlements, regions and countries in the context of climate change,

- Poverty reduction and social inclusion,

- The rule of law, democracy and security.

The priorities are based on the 17 Sustainable Development Goals contained in the UN Agenda 2030 Strategy Paper for Sustainable Development. Slovakia has chosen to combine several goals into a smaller number of national priorities relevant to our country. Representatives of the non-governmental sphere, such as representatives of non-profit organizations, the academic community, local authorities or interest groups (stakeholders), helped in creating the content of the six priorities.

At the same time, it is also necessary to create an environment that supports citizens' initiatives and innovations in the field of sustainable development. Therefore, among other instruments, a new microgrant scheme is being developed in cooperation with nongovernmental partners. This scheme will support the best initiatives and local microprojects focused on the implementation of the 2030 Agenda for Sustainable Development.

\subsection{The role of businesses in meeting sustainability objectives}

All businesses should pursue the objectives and principles of the 2030 Agenda, not only because the 2016 Paris Agreement already includes an obligation for businesses to comply with these principles, but also because of the sustainability of the enterprise itself. At present, the competitiveness and further development of each company depends mainly on its social responsibility.

Responsible behavior is the company's commitment to developing its economic activities efficiently and responsibly towards society and the environment, taking into account the interests of all stakeholders as part of the company's strategic and risk management. Responsible behavior of companies not only towards their employees, but also in relation to their surroundings should represent a continuous activity - responsible approach of the company to the community, to solving some social problem or the need of the community.

Socially responsible behavior towards the community, or community support is part of the so-called external social pillar of corporate social responsibility. A company or organization operates within the community, it is part of it. Socially responsible companies are, however, not part of the community only as market player, but also as actors in community life, seeking to create, maintain and develop good "neighborhood relations" that is beneficial for both the community and the companies themselves.

According to Lapinová, socially responsible corporate behavior towards the community includes two groups of activities in terms of form, intensity, time and systematic nature [6]:

- The most common focus is on environmental protection, support for education and assistance, and support for socially weak, young, talented or long-term unemployed citizens. 
- To a lesser extent, they are also involved in building community capacities (infrastructure, services) or, together with the non-profit and public sectors, participate in the preparation of strategic development documents in the community territory.

In a broader sense, socially responsible behavior includes also socially responsible behavior of the companies towards employees, suppliers, buyers who also live or operate within the local community, and thus are linked back with multiple relations to these businesses in the local community. Companies are also involved in tackling societal challenges in areas such as social integration (tolerance, social cohesion), health care, education, quality of life (sport, culture), economic recovery and development, local infrastructure, safety, human capital and human rights.

\section{Results and discussion}

The aim of the article is to assess the current state and development of selected indicators of sustainable development related to the quality of human capital in Slovakia and other V4 countries in the period since. 2014-2018 and compare them with the EU-28 average.

The research is based on data from the Eurostat data base from 2014 to 2018 .

To process the data, we use general scientific methods of analysis, synthesis, abstraction, induction, deduction, comparison and standard mathematical-statistical methods.

Selected indicators represent indicators of poverty and monitor compliance with the set objectives: no poverty, no hunger and quality of health and life in the context of sustainable development. In this context, we monitored the state and development of the V4 countries over the period (2014 to 2018) and compared it with the EU-28 average on the following indicators $[13,14,15,16]$ :

- Persons at risk of poverty or social exclusion in $\%$ of the population -Table 1

- Persons suffering from material deprivation in \% of the population - Table 2 (Indicator expresses the living conditions of people suffering from material deprivation, which are severely constrained due to lack of funds and are unable to cover at least six of the following nine items of expenditure: rent and energy, adequate home heating, unexpected expenditure, meat, fish or equivalent protein every other day, weekly vacation elsewhere, car, washing machine, color TV or phone

- Poverty risk rate by sex in $\%$ of employed women over 18 -Table 3

- Inhabitants living in substandard conditions in $\%$ of the total population - Table 4 (This indicator shows the population at risk of poverty living in a flat with leaking roof, moisture in walls, floors, foundations or rot in windows and floors)

- Population with unfulfilled need for medical treatment in $\%$ of total population over 16Table 5 (Indicator shows the number of people who claim that their needs for medical treatment were not fulfilled due to of high costs, long distance or waiting list)

- Changes in contracts for the indefinite period- average over three years in $\%$ of fixedterm workers -Table 6 (Indicator reflects changes in employment relationships from fixed-term employment contracts to employment contracts for the indefinite period)

- Number of 2-adult households with two children under the age of 14 living at risk of poverty (60\% median income)- Table 7.

Table 1. Persons at risk of poverty or social exclusion in\% of the population [20]

\begin{tabular}{l|l|l|l|l|l|}
2014 & 2015 & 2016 & 2017 & 2018 & Index \\
\hline
\end{tabular}




\begin{tabular}{|l|r|r|r|r|r|r|}
\hline & & & & & & $\mathbf{2 0 1 4 / 2 0 1 8}$ \\
\hline EU & 24.4 & 23.8 & 23.5 & 22.4 & 21.9 & -2.5 \\
\hline Czech Republic & 14.8 & 14.0 & 13.3 & 12.2 & 12.2 & -2.6 \\
\hline Hungary & 31.8 & 28.2 & 26.3 & 25.6 & 19.6 & -12.2 \\
\hline Poland & 24.7 & 23.4 & 21.9 & 19.5 & 18.9 & -5.8 \\
\hline Slovakia & 18.4 & 18.1 & 18.1 & 16.3 & 16.3 & -2.1 \\
\hline
\end{tabular}

If we compare the percentage of people at risk of poverty in the V4 countries with the EU average, we can say that in 2018 all V4 countries have a lower proportion of these people than the EU average. The Czech Republic and Slovakia are among the countries with the lowest shares, Hungary has this indicator as the highest. All countries in the period under review (including the EU-28 average) recorded a favorable development of this indicator. The most favorable development - the highest decrease was recorded in Hungary; the lowest decrease was recorded in Slovakia.

Table 2. Persons suffering from significant material deprivation in $\%$ of the population [20]

\begin{tabular}{|l|r|c|r|r|r|c|}
\hline & $\mathbf{2 0 1 4}$ & $\mathbf{2 0 1 5}$ & $\mathbf{2 0 1 6}$ & $\mathbf{2 0 1 7}$ & $\mathbf{2 0 1 8}$ & $\begin{array}{c}\text { Index } \\
\mathbf{2 0 1 4 / 2 0 1 8}\end{array}$ \\
\hline EU & 8.9 & 8.1 & 7.5 & 6.6 & 5.9 & -3.0 \\
\hline $\begin{array}{l}\text { Czech } \\
\text { Republic }\end{array}$ & 6.7 & 5.6 & 4.8 & 3.7 & 2.8 & -3.9 \\
\hline Hungary & 20.0 & 19.4 & 16.2 & 14.5 & 10.1 & -9.9 \\
\hline Poland & 10.4 & 8.1 & 6.7 & 5.9 & 4.7 & -5.7 \\
\hline Slovakia & 9.9 & 9.0 & 8.2 & 7.0 & 7.0 & -2.9 \\
\hline
\end{tabular}

The share of persons suffering from material deprivation compared to the EU28 is the most favorable in the Czech Republic and in 2014 in Slovakia, since. 2015 Poland has been ahead. The worst situation is in Hungary in the monitored period. The favorable trend in the monitored period shows an analogous trend to the previous indicator. Slovakia has again the lowest decrease $-2.9 \%$, Hungary the highest $-9.9 \%$

Table 3. Poverty risk rate by sex in $\%$ of employed women over 18 [20]

\begin{tabular}{|l|c|c|c|c|c|c|}
\hline & $\mathbf{2 0 1 4}$ & $\mathbf{2 0 1 5}$ & $\mathbf{2 0 1 6}$ & $\mathbf{2 0 1 7}$ & $\mathbf{2 0 1 8}$ & $\begin{array}{c}\text { Index } \\
\mathbf{2 0 1 4} / \mathbf{2 0 1 8}\end{array}$ \\
\hline EU & 9.1 & 8.7 & 9.1 & 9.0 & 9.1 & 0.0 \\
\hline Czech Republic & 3.9 & 4.5 & 3.9 & 3.7 & 3.7 & -0.2 \\
\hline Hungary & 5.9 & 8.7 & 9.9 & 10.6 & 8.9 & +3.0 \\
\hline Poland & 9.3 & 9.8 & 9.5 & 9.1 & 8.2 & -1.1 \\
\hline Slovakia & 5.3 & 5.5 & 6.0 & 5.8 & 5.8 & +0.3 \\
\hline
\end{tabular}

Comparing the development of this indicator in the monitored period shows that the persistently worst situation in this area is in Poland - the first four years the indicator slightly exceeds the EU 28 average, in 2018 is lower, the indicator is worst in Hungary- the risk of poverty among employed women increased by 3\%. The Czech Republic has the lowest percentage with favorable development. In Slovakia, however, where the situation is significantly better than the EU-28 average, this indicator worsens in 2018 compared to 2014. 
Table 4. Inhabitants living in unsatisfactory conditions in $\%$ of the total population [20]

\begin{tabular}{|l|c|c|c|c|c|c|}
\hline & $\mathbf{2 0 1 4}$ & $\mathbf{2 0 1 5}$ & $\mathbf{2 0 1 6}$ & $\mathbf{2 0 1 7}$ & $\mathbf{2 0 1 8}$ & $\begin{array}{c}\text { Index } \\
\mathbf{2 0 1 4 / 2 0 1 8}\end{array}$ \\
\hline EU & 15.7 & 15.2 & 15.4 & 13.3 & 13.9 & -1.8 \\
\hline Czech Republic & 9.2 & 8.9 & 8.2 & 8.0 & 7.7 & -1.5 \\
\hline Hungary & 26.9 & 25.4 & 26.7 & 24.8 & 22.5 & -4.4 \\
\hline Poland & 9.2 & 11.9 & 11.6 & 11.9 & 11.6 & +2.4 \\
\hline Slovakia & 7.0 & 6.3 & 6.2 & 6.7 & 5.1 & -1.9 \\
\hline
\end{tabular}

In contrast to the previous comparisons, the situation in the percentage of the population living in substandard conditions in $\%$ of the total population is completely different. Slovakia is on the first place from all V4 countries and it also exceeds the EU 28 average. The fact that the percentage fell by $1.9 \%$ in the monitored period can be considered as positive. The worst situation is Hungary, which exceeds the EU-28 average by approximately $10 \%$ in the monitored period. It shows, however, a positive trend - a decrease of $4.4 \%$

Table 5. Residents with unfulfilled medical need in\% of total population over 16 years [20]

\begin{tabular}{|l|c|c|c|c|c|c|}
\hline & $\mathbf{2 0 1 4}$ & $\mathbf{2 0 1 5}$ & $\mathbf{2 0 1 6}$ & $\mathbf{2 0 1 7}$ & $\mathbf{2 0 1 8}$ & $\begin{array}{c}\text { Index } \\
\mathbf{2 0 1 4} / \mathbf{2 0 1 8}\end{array}$ \\
\hline EU & 3.6 & 3.3 & 2.6 & 1.7 & 2.0 & -1.6 \\
\hline Czech Republic & 1.1 & 0.8 & 0.7 & 0.5 & 0.3 & -0.8 \\
\hline Hungary & 2.5 & 2.6 & 1.3 & 1.0 & 0.8 & -1.7 \\
\hline Poland & 7.8 & 7.3 & 6.6 & 3.3 & 4.2 & -3.6 \\
\hline Slovakia & 2.1 & 2.1 & 2.3 & 2.4 & 2.6 & +0.5 \\
\hline
\end{tabular}

The share of people experiencing inadequate medical care in the monitored period is the lowest in the Czech Republic, followed by alternating developments in Hungary and Slovakia. While the situation in Hungary improved, it worsened in Slovakia as the only of V4 countries. The most dissatisfied inhabitants are in Poland, but the country shows a significant improvement - almost by $4 \%$.

Table 6. Changes in contracts for indefinite period-average for three years in $\%$ of fixed-term employees [20]

\begin{tabular}{|l|r|r|r|r|r|r|}
\hline & $\mathbf{2 0 1 4}$ & $\mathbf{2 0 1 5}$ & $\mathbf{2 0 1 6}$ & $\mathbf{2 0 1 7}$ & $\mathbf{2 0 1 8}$ & \multicolumn{1}{c|}{$\begin{array}{c}\text { Index } \\
\mathbf{2 0 1 4 / 2 0 1 8}\end{array}$} \\
\hline EU & 23.6 & 23.2 & 24.1 & 24.7 & 24.5 & +0.9 \\
\hline Czech Republic & 33.5 & 35.1 & 36.5 & 39.6 & 42.9 & +9.4 \\
\hline Hungary & 38.0 & 38.5 & 37.2 & 32.6 & 31.2 & -6.8 \\
\hline Poland & 18.4 & 18.8 & 22.0 & 25.7 & 30.0 & +11.6 \\
\hline Slovakia & 39.4 & 35.7 & 36.0 & $\mathrm{x}$ & $\mathrm{x}$ & $\mathrm{x}$ \\
\hline
\end{tabular}

In terms of the share of changes in contracts of indefinite period in Slovakia, Hungary and the Czech Republic, this indicator is significantly more favorable than the EU average, unlike in Poland, which lags behind in this area in the first 3 years. While this trend of development is unfavorable in Hungary- the decline is almost 7\%, in Poland it is increasing considerably - by almost $12 \%$. Data for Slovakia for the last two years are not available. 
Table 7. Number of households at the poverty line with $60 \%$ median income [20]

\begin{tabular}{|l|c|c|c|c|c|c|}
\hline & $\mathbf{2 0 1 4}$ & $\mathbf{2 0 1 5}$ & $\mathbf{2 0 1 6}$ & $\mathbf{2 0 1 7}$ & $\mathbf{2 0 1 8}$ & $\begin{array}{c}\text { Index } \\
\mathbf{2 0 1 4} / \mathbf{2 0 1 8}\end{array}$ \\
\hline Czech Republic & 9,604 & 9,353 & 9,876 & 10,435 & 11,451 & $+19,2 \%$ \\
\hline Hungary & 5,686 & 5,741 & 6,007 & 6,285 & 6,834 & $+20,2 \%$ \\
\hline Poland & 6,724 & 7,000 & 7,413 & 7,491 & 8,283 & $+23,2 \%$ \\
\hline Slovakia & 8,580 & 8,732 & 8,758 & 9,051 & 9,402 & $+9,6 \%$ \\
\hline
\end{tabular}

When comparing the number of households at the poverty line, the highest number of households at risk is in the Czech Republic, followed by Slovakia and Poland. The lowest number of households at risk of poverty is in Hungary. In terms of development trend, growth is the highest in Poland and the lowest in Slovakia.

The results of the survey, which represent a comparison of the development of selected sustainability indicators in the V4 countries between 2014 and 2018, confirm that Slovakia is not characterized by a significant improvement if compared with its initial position. There is a stagnation in this area rather, which in the long term poses a risk of deterioration in the quality of human capital in Slovakia and thus its potential as a source of innovative development of the country.

\section{Conclusion}

Ensuring the fulfillment of sustainable development goals, defined and adopted at the UN and EC levels and transformed into the national strategy of the Slovak Republic, as well as their subsequent consistent application in everyday economic practice, is a prerequisite for further development of the knowledge economy of the Slovak Republic. This requires, however, strategic, targeted state measures to facilitate the creation of optimal conditions for all economic actors to fully exploit available human capital.

\section{Acknowledgement}

This paper is the outcome of projects: VEGA No. 1/0569/18 (50\%) \& VEGA No. 1/0309/18 (50\%) - funded by the University of Economics in Bratislava; with the project membership of both authors.

\section{References}

1. BPB 2008. Leitbild der Nachhaltigen Entwicklung. Available online: https://www. bpb.de/izpb/8983/leitbild-der-nachhaltigen-entwicklung? $\mathrm{p}=$ all. [accessed 28.03.2020].

2. EK 2020. Prístup EÚ k trvalo udržatel'nému rozvoju. Available online: https://ec.europa.eu/info/strategy/international-strategies/sustainable-developmentgoals/eu-approach-sustainable-development_sk. [accessed 28.03.2020].

3. IHK 2020. Aspekte der Nachhaltigkeit. Available online: https://www.nachhaltigkeit. info/artikel/politik_1976.htm. [accessed 28.03.2020].

4. LS 2020. Strategien und Programme der Europäischen Union. Available online: https:// ec.europa.eu/environment/sustainable-development/SDGs/index_en.htm. [accessed 28. 03. 2020]. 
5. Nachhaltigkeit. Available online: https://www.nachhaltigkeit.steiermark.at/cms/ziel/ 139358118/DE/. [accessed 28.03.2020].

6. Lapinová, E. 2013. Spoločenská zodpovednost' firiem a jej význam pre miestny a regionálny rozvoj. Available online: http://www.ef.umb.sk/dsr_2013/pdf/\%C4\% BDapinov\%C3\%A1.pdf. [accessed 28.03.2020].

7. Národná stratégia trvalo udržatel'ného rozvoja 2001. Available online: https:// hpur.vlada.gov.sk/data/files/5636_narodna-strategia-trvalo-udrzatelneho-rozvoja.pdf. [accessed 28.03.2020].

8. Agenda 2030 pre udržatel'ný rozvoj. 2018. Available online: https://www.minzp.sk/ agenda-2030/. [accessed 28.03.2020].

9. UNIS. 2020. Ciele udržatel'ného rozvoja. Available online: http://www.unis.unvienna. org/unis/sk/topics/sustainable_development_goals.html\#.[accessed 28.03.2020].

10. Z. Kapsdorferová, M. Kadlečíková, E. Svitová, Utilization of quality managerial systems in business entities in the Slovak Republic. International Journal for Quality Research 9, 2, 197-208 (2015).

11. A. Pilkova, M. Holienka, Entrepreneurship Development in Slovakia. Entrepreneurship in Transition Economies: Diversity, Trends, And Perspectives, Book Series: Societies and Political Orders in Transition, Pages: 225-241 (2017).

12. J. Blštáková, Z. Joniaková, Z. Skorková, I. Némethová, R. Bednár, Causes and Implications of the Applications of the Individualisation Principle in Human Resources Management. AD ALTA journal of interdisciplinary research. MAGNANIMITAS 9, 2, 323-327 (2019).

13. M. Szarková, Reasons of Employees' Fluctuations from the Perspective of Employers in the Slovak Republic. Hradec Economic Days 2019. International Scientific Conference. Hradec Economic Days 2, 404-413 (2019).

14. T. Bobenič, A. Bobenič Hintošová, L. Hliboká, I. Vasková, Effects of changes in steel industry concentration. Croatian Metallurgical Society 54, 3, 571-574 (2015).

15. A. Bobenič Hintošová, Z. Kubíková, The Effect of the degree of foreign ownership on firms' performance. Národohospodářský obzor 16, 1, 29-43 (2016).

16. S. Goda, Slovakia and international crisis management: Focus Ukraine. Medzinárodné vzt’ahy 2015. Aktuálne otázky svetovej ekonomiky a politiky. Medzinárodná vedecká konferencia. Medzinárodné vzt'ahy 16, 293-297 (2015).

17. A. Remišová, A. Lašáková, Z. Kirchmayer, Infuence of Formal Ethics Program Components on Managerial Ethical Behavior. Journal of Business Ethics 160, 151 166 (2019).

18. K. Pavlyk, J. Péliová, Social enterprises in Slovakia and Ukraine: focus on finances. Finance and risk 2015. International scientific conference. Finance and risk 17, 233241 (2015).

19. E. Pastoráková, Z. Brokešová, Risks covered by pension systems and the possibility of individual saving for old age. Managing and modelling of financial risks. International scientific conference. Managing and modelling of financial risks 8, 783-790 (2016).

20. Eurostat 2020. Available online: https://ec.europa.eu/info/statistics/search-eurostatstatistics_en. [accessed 28.03.2020]. 